\title{
Satisfaction and Service Quality in Indian Railways - A Study on Passenger Perspective
}

\author{
V.Rajeswari ${ }^{1}{ }^{1}$ K.Santa kumari ${ }^{2}$ \\ ${ }^{1}$ Research Scholar, Dept. of Economics, Sri Venkateswara University, Tirupati-517502 \\ ${ }^{2}$ Professor, Dept of Economics, Sri Venkateswara University, Tirupati -517502
}

\begin{abstract}
Customer satisfaction and retention is one of the key determinants to measure the quality of products or services and hence the Indian Railway performance. Due to the growing importance of quality in our life, customers desire to enjoy a relatively better quality of products or availing superior quality services has been increased. India is the Second highly populated country of the world and its rapid population growth also contributes to an increase of people's travelling demands. In Indian Passenger trains is the cheapest and comfortable mode of travelling especially for long distances. This paper aims to investigate the passengers' perceptions about the service quality of rail transport system in Indian Railways while travelling between the major cities especially from Kerala to Delhi, Mumbai and Delhi. A modified SERVQUAL instrument including eight service quality constructs: Reliability, assurance, tangibles, timeliness, responsiveness, information system, empathy, food and safety and security were employed to measure the passengers" perceptions about the service quality of railways. Out of 500 respondents, only 442 were selected and these respondents were frequent railway traveller on these routes. Results indicate that passengers perceive that quality of services delivered to them is not satisfactory.
\end{abstract}

Key words: Service quality, Rail transport Passenger, satisfaction, SERVQUAL

\section{Introduction}

Organizations and companies succeed, or fail, based on the quality and effectiveness of their employees. Today's successful firms recognize that to compete in global markets, they must have world class Human Resource managers who are active participants in strategic and operational decision. Whether they are reengineering the pay and benefits of the company or implementing Total Quality Management (TQM) programs, Human Resources Managers play a central role. Most importantly, the practice of Human Resource Management is undergoing a technological revolution. We speak now of managing not only human resources and capital, but also information and information systems. HR functions, from employee selection to benefits planning, are being redesigned to take advantage of advanced information technology.

Quality is one of the key parameters in order measure the performance of the products or services and even it is one primary indicator to organizational performance. It is meant to help the organization train, motivate and reward workers. It is also meant to ensure that the organizational goals are met with efficiency. The process not only includes the employees but can also be for a department, product, service or customer process; all towards enhancing or adding value to them. Nowadays there is an automated performance management system (PMS) that carries all the information to help managers evaluate the performance of the employees and assess them accordingly on their training and development needs. Earlier quality was considered only for the manufacturing sector but during the last couple of decades there is a tremendous growth in service sector around the globe and concept of quality has arisen in this sector. It is evident from the literature that now service sector has become one of the fastest growing sectors in global economy and the major reason is that now the American economy has become a service economy [1]. Manufacturing and construction sector in United States employed $19.1 \%$ of the labour force which had been reduced from $26.1 \%$ in 1979 whereas service sector had employed 70\% of the U.S labour in 1992 [2]. Service sector is growing in almost all the economies of the world and the similar growth trend can also be seen in the India. According to Indian Railways [3](2010-11), 25 $\%$ of the GDP is contributed by service sector $(24.3 \%)$.

Service sector has realized that service quality is the main source of gaining competitiveness and remains successful in the market [3] and many other researchers had emphasized that quality initiatives in the service sector had resulted in gaining sustainable competitive advantages [4,5,6,7,8 ]. According to [1], it is evident from the EBSCO academic electronic database that only 15 studies had been conducted during 1989 to 1991 and 198 studies were conducted during 1997-1999 and 138 studies through 1999-2001, which indicates that concept of service quality has been increasingly important topic for the service industry. Hence, service quality is a subject that gains considerable interest of both the academicians and the service providers. Now the Service organizations had started putting their maximum effort towards customer-focused services and thus continuous performance improvement. 
As customer perception plays a significant role in order to measure service quality of the service provider and hence the performance of the organization. It is also evident from the literature that superior quality of services helps to gain customer satisfaction, loyalty, increased market share and thus increased productivity and performance [8-14].

In order to measure how customers perceive about the quality of public transport, there are some evidence from the literature that customers (passengers) perceive: that reliability, timing, frequency and fare $[15,16]$, cleanliness and comforts $[17,18]$, transport network and coverage which also includes the stoppages $[15,19]$, safety issues $[20,21]$ and information system [22] are considered to be important factors in order to evaluate the service quality. Evidences suggested quality of services

leads to enhanced productivity and thus increase profitability, positive word-of-mouth, market share, return on investment and ultimately reduced costs that benefits the customers [23]. This trend of evaluating the customer requirements and delivering services according to customer requirements is now seen in the developing countries.

This study aims to investigate the customers (passengers) perceptions about the service quality of only available public rail transport system in India. Demand for public transportation is high due to its rapid population growth. Trains, a major public transport, in India hold a unique position in the transportation sector of country and are considered to be the key determinant for the national growth. Transportation sector is still passing through its transformational stage as it is still insufficient to serve the fastest growing 121 Crores population of India. However, still with inadequate resources transportation sector is one of the growing sectors of Indian economy and contributing $24.42 \%$ of GDP. There is a growth in the road networks, development of new national highways and an additional motorways network; but rail transport system was lacking from the development and growth process. Most of the railway tracks were built before 1947 during the British rule in Indo-Pak. Rail transport system is a public sector rail transport service known as Indian Railways and is one of the oldest systems and is administered by the Government of India and runs under ministry of Railways. Indian railways are commonly referred to as the "as "Provide what is better" "Promote what is best" Preserve what is good", by making movement of people and freight thought Indian at large scale. Currently, all major cities of India are connected with rail transport network. During the couple of decades rail transport system is towards its worst decline. Therefore, there is a dearth of research to measure the service quality in India in general and to measure the passengers' perception about the quality of service delivered by the transport sector in particular. Uniqueness of this study is that there is no such work had been evident from the literature on this topic. Structural equation modeling (SEM), one popular technique, was employed to explore the relationship among the service quality attributes and passengers' satisfaction.

\section{Literature Review}

Service quality can be described as a rationale of differences between expectation and competence along the important quality dimensions. Parasuraman, Zeithaml and Berry [24] identified ten requirements useful for Passengers' evaluation of the quality of services: reliability, responsiveness, tangibles, Information, Assurance, Empathy, Food plazas, timeliness, understanding the Passengers and service accessibility. Zeithaml, Parasuraman, and Berry [25] proposed a service quality scale (SERVQUAL), a generic instrument that has 8 dimensions of service quality: reliability, responsiveness, assurance, empathy and tangibles, the constructs were found to have high correlation.

This instrument continues to be widely used in marketing studies of customer satisfaction and consumer preference [26], despite some argument that other models may be better [27] [28] [29] and [30]. The stage of performance that a top quality service will need to give was conditioned through the expectation of the customers. Service quality is judged low when the performance was below expectation. In the present study, a modified SERVQUAL instrument was employed to measure the service quality of railways.

SERVQUAL: Due to intangible in nature service quality is difficult to measure as compare to products and the characteristics of service appears to be difficult and considered as a complicated task [31, 32]. The first comprehensive service quality model was coined by the [25]. He further stated that service quality is influenced by five gaps and earlier this model was known as gap model. Difference between customer expectations and management perceptions about the customer expectations were represented as 'gap 1', the difference between the management perceptions about the customer expectations and then translate these perception in to service quality specification was represented as 'gap 2', difference between the actual services delivered by the front line service employees on daily basis and the management specifications is represented as 'gap 3', the difference between the service delivery and what is promised to consumers in external communication is represented as 'gap4' and finally the difference between customer expectations and perceptions were represented as 'gap 5'. SERVQUAL instrument was based on 'gap 5. Later on [25] came out with the 10 dimensions of service quality. These ten dimensions were then reduced to 5 dimensions namely; empathy, assurance, tangibles, reliability and 
responsiveness and these five constructs were further represented by 22 items. Today, SERVQUAL is most commonly used model in order to measure the service quality and it had been used in almost all the countries and in all types of industries [31]. According to [31], SERVQUAL has been successful used in healthcare, fast food, banking, telecommunication, retail chains, information systems, library services and many countries around the globe like; USA, China, Australia, Cyprus, Hong Kong, Korea, South Africa, Netherland and UK.

Rail Transport System in India: Rail transport system is the main public transport system in India and is administered by the Federal Government of India namely, Indian Railways. Rail transport system is connected with all the major cities of the country. Rail transport system is aiding movement of the people with lowest fare and the source of transportation from big cities like Delhi, Chennai, Mumbai, Kolkata, Bangalore and Hyderabad. Especially on these routes, a number of nonstop trains are operated in order to minimize the time and reduce the distances. According to Annual reports of Indian Railways, it carries about 8500 Million passengers per day and about 84,26 Lakhs passengers during the year of 2011-2012.

Indian Railways is hence labelled as "Provide what is better" "Promote what is best" Preserve what is good" with is then true. The total length of the rail tracks is about 64,600 route kilometres covering 7146 railway stations in India. Indian Rail transport system is also connected with two neighbouring countries like Pakistan and Nepal. On the basis of the above discussion and through literature review the following eight hypotheses were developed.

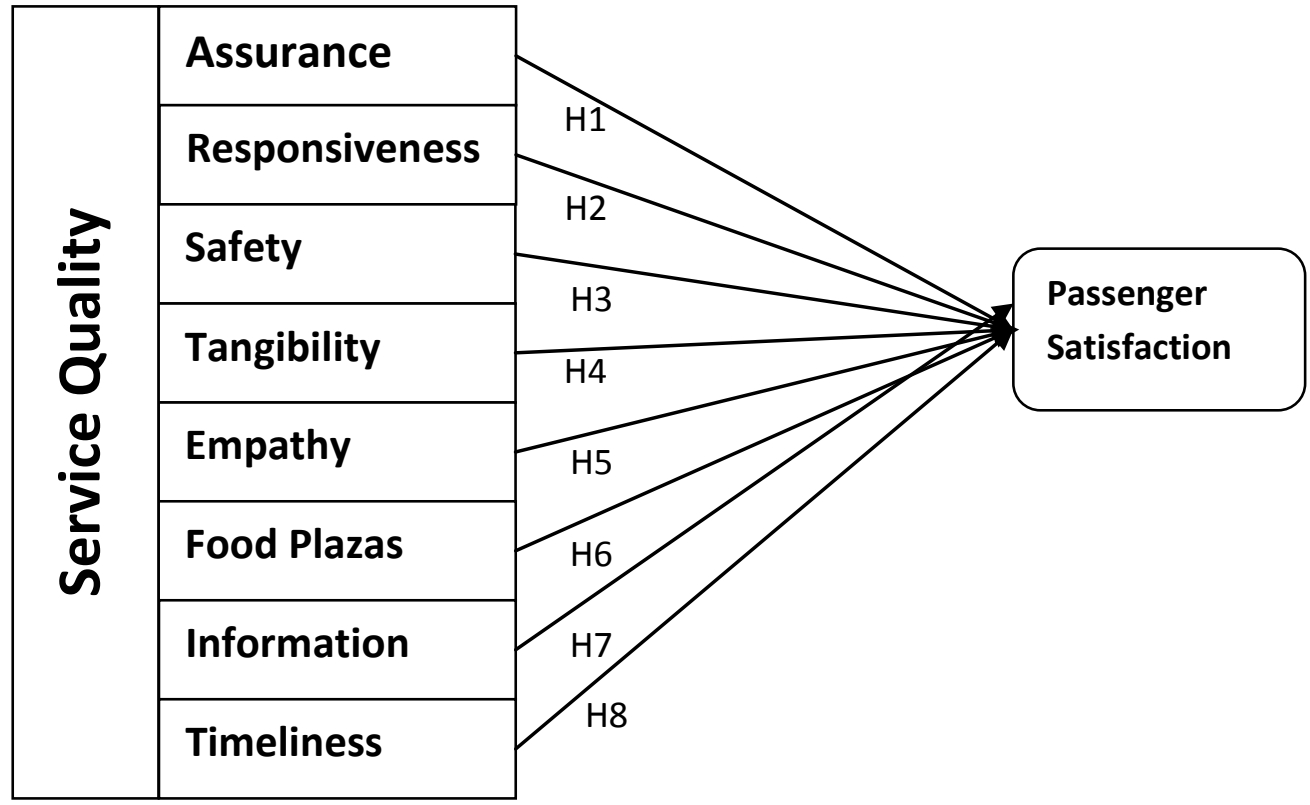

Research Frame Work

H1: Assurance will have a significant impact on passenger satisfaction

H2: Responsiveness will have a significant impact on passenger satisfaction

H3: Safety will have a significant impact on passenger satisfaction

H4: Tangibility will have a significant impact on passenger satisfaction.

H5: Empathy will have a significant impact on passenger satisfaction

H6: Food plazas will have a significant impact on passenger satisfaction

H7: Information will have a significant impact on passenger satisfaction

H8: Timeliness will have a significant impact on passenger satisfaction

\section{Methodology:}

This research was carried out by to measure the service quality of Indian Railways based on passengers' perceptions that are frequent travel on nonstop trains operated from Delhi to other big cities such as, Mumbai, Kolkata, Chennai, Bangalore and Hyderabad. A modified SERVQUAL instrument was used to develop the questionnaire for evaluation of service quality of Indian Railways on the basis of passenger's perceptions. This questionnaire consists of eight constructs which include 
tangibles, assurance, Punctuality, responsiveness, empathy, safety, Catering, Information are representing the independent variables and passenger satisfaction is used as dependent variable. Five point Likert scale from highly satisfied " 5 " to least satisfied " 1 " was employed in the present study.

Reliability and validity of the data was measured using confirmatory factor analysis. Relationship between latent and exogenous variables was analyzed using SEM through AMOS 16.0 and SPSS 16.0. SEM is an effective and most commonly used technique in most of the management, social sciences studies. SEM is an effective model testing technique that is path analytic which includes both the latent and exogenous variables.[32].

A total 500 questionnaires were distributed among the passengers travelling from Vijayawada division to other cities of the country on fast moving and nonstop trains. Out of 500 questionnaires, 68 questionnaires were incomplete or the respondents were not using nonstop trains and thus rejected. Therefore, a total 442 questionnaires was used in the study and thus providing a very good response rate of $80.42 \%$. Personal efforts were made in order to collect the data along railway staff and researcher. As the questionnaire was developed in English and thus to get an accurate response researcher assist the respondents in case of any confusion about the question. Major reason for selecting the train as a mode of journey from Vijayawada to Hyderabad especially is that a very few alternatives are available due to long distance, however between the other cities the people with families, prefer to travel through trains due to less fair and ease of travelling. As only trains are operating in public sector and provide compensations in fares, whereas, no other road transport mean buses are operating under public sector. Therefore, cheap fares, easy to travel with families and luggage on long distances are the major reason of the selection of train system. The demographic of the present study is presented as below Table 1.

The demographic characteristics of the respondents are shown in table 1 . The gender distribution of the respondent passengers groups was quite uneven, with 76.4 per cent male respondents and 23.6 per cent female respondents. The model age group of the respondents was 31 - 40 years (38.3 per cent), followed by $41-50$ years (31.2 per cent), 51 and above (16.5 per cent), and 20-30 years (14.1 per cent).

Most of the respondents (48.1 per cent) reported that they came from places in Andhra Pradesh, and 40.3 per cent from places within India but outside of AP, 11.7 per cent from outside India. In terms of level of education, 27 per cent of the respondents are graduates; 24.3 per cent Professionals, and 18.2 per cent are undergraduates or with 10 plus two education level. 17.5 Post-graduate and beyond, and 11.7 per cent with secondary school of education. The results show that sample respondents have relatively high educational attainment. In terms of occupation, 22.7 per cent respondents are businessmen/industrialist, 21.0 per cent respondents government servants. 19.5 per cent respondents professionals (including software engineers, doctors, lawyers, etc.) 17.5 per cent private service employees, 10.4 per cent respondents contractors, realtors, etc., and 8.9 agriculturists (includes formers, landlords, etc.).

Table.1: Demographic Characteristics of the Respondents

$(N=462)$

\begin{tabular}{|l|l|l|l|}
\hline S.No & Variable & Freq. & Per cent \\
\hline $\mathbf{1}$ & Gender & 353 & \\
\hline a & Male & 109 & 76.4 \\
\hline b & Female & 23.6 \\
\hline $\mathbf{2 .}$ & Age(in Yrs) & 65 & 14.1 \\
\hline a & $20 .-30$ & 177 & 38.3 \\
\hline b & $31-40$ & 144 & 31.2 \\
\hline c & $41-50$ & 76 & 16.5 \\
\hline d & 51 \& above & & \\
\hline 3. & State & 222 & 48.1 \\
\hline a & With in AP & 186 & 40.3 \\
\hline b & Out of AP & 54 & 11.7 \\
\hline c & Out of India & \\
\hline $\mathbf{4}$ & Education & 54 & 11.7 \\
\hline a & Upto Secondary & 84 & 18.2 \\
\hline b & Under Graduate & 128 & 27.7 \\
\hline c & Graduate & 81 & 17.5 \\
\hline d & PG \& Above & 115 & 24.9 \\
\hline e & Technical / Professional & \\
\hline
\end{tabular}

\begin{tabular}{|l|l|l|l|}
\hline S.No & Variable & Freq. & Per cent \\
\hline $\mathbf{5}$ & Occupation & 90 & \\
\hline A & Professional & 81 & 19.5 \\
\hline B & Private Service & 105 & 17.5 \\
\hline C & Business/Industrialist & 97 & 22.7 \\
\hline D & Govt. Servant & 41 & 8.0 \\
\hline E & Formers/ Landlords & 48 & 10.4 \\
\hline F & Others & 63 & 13.6 \\
\hline 6. & Total household income(in Rs) p.a \\
\hline A & Below 80000 & 112 & 24.2 \\
\hline B & $80001-100000$ & 70 & 15.2 \\
\hline C & $100001-120000$ & 72 & 15.6 \\
\hline D & $120001-1,40,000$ & 83 & 18.0 \\
\hline E & $1,40001-160,000$ & 62 & 13.4 \\
\hline F & Above 1.60 lakhs & \multicolumn{2}{|l|}{} \\
\hline
\end{tabular}

Source: Primary data.

the respondents were highly educated with master degree (16 years of education). $63 \%$ of the respondents was travelling with families and children or travelling with their friends. The highest number of travellers were from Lahore to Karachi which are $68 \%, 33 \%$ passengers were travelling from Lahore to Rawalpindi, $14 \%$ of the passengers were travelling from Lahore to Multan and the lowest number of respondents were travelling from Lahore to Peshawar which was only $8 \%$. 
Table : 2 Descriptive Statistics

\begin{tabular}{|l|l|l|l|l|}
\hline S.No & Variables & N & Mean & S.D \\
\hline 1 & Assurance & 442 & 3.70 & 1.097 \\
\hline 2 & Responsiveness & 442 & 3.67 & 1.129 \\
\hline 3 & Safety & 442 & 3.57 & 1.211 \\
\hline 4 & Tangibility & 442 & 3.53 & 1.113 \\
\hline 5 & Empathy & 442 & 3.46 & 1.178 \\
\hline 6 & Food plazas & 442 & 3.33 & 1.216 \\
\hline 7 & Information & 442 & 3.39 & 1.270 \\
\hline 8 & Timeliness & 442 & 3.45 & 1.306 \\
\hline
\end{tabular}

Statistical Analysis: To measure the reliability of the instrument Cronbach Alpha was calculated as reliability and validity of the instrument which plays a significant role while performing the statistical analysis and consistency in the results [33] and reliability of the data [34]. [35], stated that a value of Cronbach Alpha greater than 0.70 is acceptable. The Cronbach Alpha for this study is 0.78 providing an acceptable value. This research is aimed to explore the relationship among the service quality of Indian Railways and the passenger's perceptions about quality of services delivered to them.

\section{Hypothesis Testing: Service Quality Dimension and Customer Satisfaction}

The regression results reported in Table 3 showed that the Eight perceived service quality dimensions explained $60.5 \%$ of the customer satisfaction towards the Indian railways $(F=162.08, p<0.01)$, thereby confirming the fitness of the model. We found out that staff responsiveness has the strongest effect on the customer satisfaction $(\beta=0.264, p<0.01)$, followed by Catering $(\beta=0.226, p<0.01)$, Tangibility $(\beta=0.203$, $p<0.01)$. Assurance $(\beta=0.181, p<0.05)$, and However, was found to be insignificant towards customer satisfaction is Safety, Empathy, Information, and punctuality.

Table 3 : Hypothesis Testing Results $(n=442)$

\begin{tabular}{|c|c|c|c|c|c|c|}
\hline Hypothesis & Path & $\mathbf{B}$ & SE B & $\beta$ & p-value & Result \\
\hline H1 & Assurance $\longrightarrow$ PS & 0.154 & 0.037 & 0.181 & $0.030^{*}$ & Accept \\
\hline H2 & Responsiveness $\longrightarrow$ PS & 0.162 & 0.049 & 0.264 & $0.001 * *$ & Accept \\
\hline H3 & Safety $\longrightarrow$ PS & 0.186 & -0.11 & 0.176 & $0.320^{@}$ & Reject \\
\hline H4 & Tangibility $\longrightarrow P S$ & 0.070 & 0.042 & 0.194 & $0.000 * *$ & Accept \\
\hline H5 & Empathy $\longrightarrow \mathrm{PS}$ & 0.255 & -0.04 & 0.156 & $0.072^{@}$ & Reject \\
\hline H6 & Catering $\longrightarrow$ PS & 0.141 & 0.061 & 0.226 & $0.000 * *$ & Accept \\
\hline H7 & Information $\longrightarrow S$ & 0.158 & -0.14 & 0.203 & $0.124^{@}$ & Reject \\
\hline H8 & Punctuality $\longrightarrow S$ & 0.126 & 0.026 & 0.201 & $0.058^{@}$ & Reject \\
\hline
\end{tabular}

The results provide statistical evidence to support identified determinants of customer satisfaction as Assurance, Responsiveness, Safety, Tangibility, Empathy, Catering, information and Punctuality Behavior towards passengers.

$>$ Latent variable assurance is represented by six items and has significant p-values; however this latent variable has a very low standardized regression weight 0.05 with significant $p$-value 0.030 shows that assurance has a Moderate impact on passenger Satisfaction

$>$ We use three items each to discuss the two latent variables responsiveness these latent variable has a positive standardized regression weights but providing a significant $\mathrm{p}$-values. The result indicates that passengers provide satisfaction with latent variables responsiveness.

$>$ We use 6 items to describe the latent variable tangible and all these items have p-value less than 0.05 which provides insights that all the items gave significant results in defining the latent variable tangible and this latent variable has standardized coefficient 0.42 with p-value 0.000 providing an insights that tangibles has a significant on passenger satisfaction.

$>$ Latent variable empathy is represented by four items and all of these items have a significant $\mathrm{p}$-value but this latent variable has a standardized regression weight -0.004 and insignificant p-value 0.072 shows that empathy has a negative impact on passenger satisfaction.

$>$ We use three items each to represent the three latent variables Catering, information and safety respectively. Safety and information has a negative regression weights, whereas catering has a positive regression weight but all these three construct has insignificant p-value representing passenger's dissatisfaction with these construct.

Summarizing the above results obtained from the estimated path diagram indicates that all the latent variables have significant impact on satisfaction and thus accepting our hypothesis Fig 1

Only tangibles have a positive and significant impact on passenger satisfaction and thus rejecting our null hypothesis. Table 3 represents all results of testing hypothesis. 
To examine the bi-variate relationship among the independent variables used to measure the service quality of rail system in India a Pearson correlation analysis was carried out. Table 4 provides the results of correlation analysis of the studied variables and it have been observed that correlation coefficient for the studied variables are ranging from 0.478 to 0.156 .

Results indicate that there is a positive and significant relationship among the service quality constructs. Highest and significant correlation is among Assurance and Responsiveness with $(r=0.478$ and $p<0.01)$. It means that improvement in the tangibles means cleanliness at platforms, in the coaches, comfort at coaches helps to increase the individual care of the passengers among employee involved at all levels of transport operations. The weakest and significant relationship is among Punctuality and Assurance provided to passengers $(r=0.156$ and $p<0.01)$.

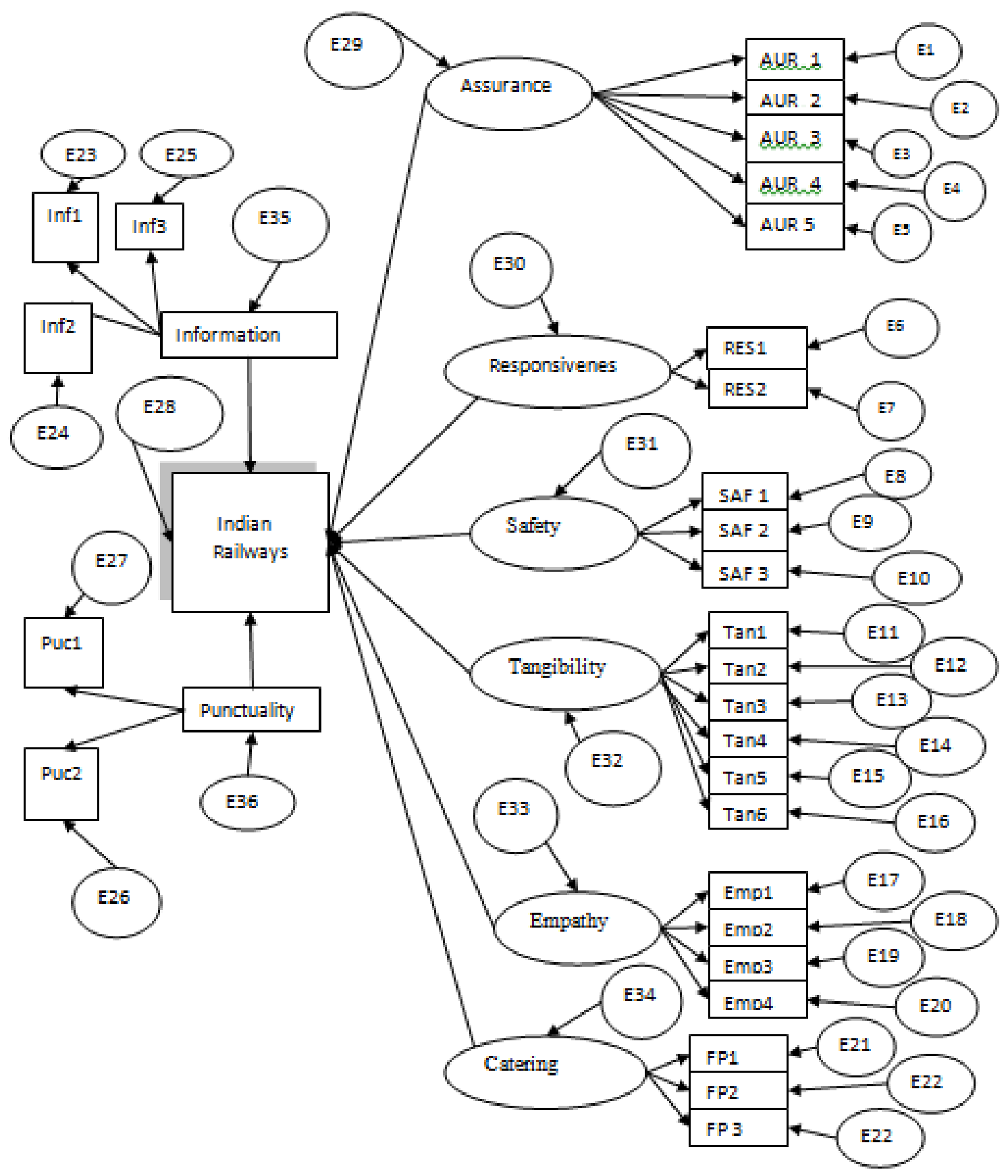

Fig : 1 Path Diagrams and Jargon of proposed model. 


\begin{tabular}{|c|c|c|c|c|c|c|c|c|c|}
\hline \multicolumn{10}{|c|}{ Correlations } \\
\hline & & Assurance & Responsiveness & Safety & Tangibility & Empathy & Catering & Information & Punctuality \\
\hline \multirow[t]{3}{*}{ Assurance } & Pearson Correlation & 1 & $.478^{* 1}$ & $.328 * 1$ & $.236^{* 1}$ & $.239^{* *}$ & $.277^{\text {**ax }}$ & $.268^{\star \star x}$ & $.156^{\star}$ \\
\hline & Sig. (2-tailed) & & .000 & .000 & .000 & .000 & .000 & .000 & .001 \\
\hline & $\mathrm{N}$ & 440 & 440 & 440 & 440 & 440 & 440 & 440 & 440 \\
\hline \multirow[t]{3}{*}{ Responsiveness } & Pearson Correlation & $.478 *$ & 1 & $.352^{\star * 1}$ & $.262^{\star 1}$ & $.210^{* 1}$ & $.237^{\star \star 1}$ & $.197^{\star \star}$ & $.186^{\star \star}$ \\
\hline & Sig. (2-tailed) & .000 & & .000 & .000 & .000 & .000 & .000 & .000 \\
\hline & $\mathrm{N}$ & 440 & 440 & 440 & 440 & 440 & 440 & 440 & 440 \\
\hline \multirow[t]{3}{*}{ Safety } & Pearson Correlation & $.328 *$ & $.352^{* 1}$ & 1 & $.234^{\star \prime}$ & $.248^{\star \star 1}$ & $.256^{\text {* }}$ & $.176^{* \star}$ & .018 \\
\hline & Sig. (2-tailed) & .000 & .000 & & .000 & .000 & .000 & .000 & .714 \\
\hline & $\mathrm{N}$ & 440 & 440 & 440 & 440 & 440 & 440 & 440 & 440 \\
\hline \multirow[t]{3}{*}{ Tangibility } & Pearson Correlation & $.236^{\star}$ & $.262^{* * 1}$ & $.234^{* * 1}$ & 1 & $.336^{\star \star x}$ & $.196^{\star *}$ & $.214^{\star \star}$ & $.112^{*}$ \\
\hline & Sig. (2-tailed) & .000 & .000 & .000 & & .000 & .000 & .000 & .019 \\
\hline & $\mathrm{N}$ & 440 & 440 & 440 & 440 & 440 & 440 & 440 & 440 \\
\hline \multirow[t]{3}{*}{ Empathy } & Pearson Correlation & $.239 *$ & $210^{\star * 1}$ & $.248^{*}$ & $.336^{\star 1}$ & 1 & $.326^{\star x}$ & $.325^{\star \star}$ & $.219^{\star \prime}$ \\
\hline & Sig. (2-tailed) & .000 & .000 & .000 & .000 & & .000 & .000 & .000 \\
\hline & $\mathrm{N}$ & 440 & 440 & 440 & 440 & 440 & 440 & 440 & 440 \\
\hline \multirow[t]{3}{*}{ Catering } & Pearson Correlation & $.277^{\star \prime}$ & $.237^{* * 1}$ & $.256^{\star * 1}$ & $.196^{\star \prime}$ & $.326^{\star *}$ & 1 & $.380^{* \star}$ & $.278^{\star}$ \\
\hline & Sig. (2-tailed) & .000 & .000 & .000 & .000 & .000 & & .000 & .000 \\
\hline & $\mathrm{N}$ & 440 & 440 & 440 & 440 & 440 & 440 & 440 & 440 \\
\hline \multirow[t]{3}{*}{ Information } & Pearson Correlation & $.268^{*}$ & $.197^{\star \star x}$ & $.176^{*}$ & $.214^{\star \prime}$ & $.325^{\star k}$ & $.380^{* 1}$ & 1 & $.261^{\star \star}$ \\
\hline & Sig. (2-tailed) & .000 & .000 & .000 & .000 & .000 & .000 & & .000 \\
\hline & $\mathrm{N}$ & 440 & 440 & 440 & 440 & 440 & 440 & 440 & 440 \\
\hline \multirow[t]{3}{*}{ Punctuality } & Pearson Correlation & $.156^{*}$ & $.186^{* *}$ & .018 & $.112^{\star}$ & $.219^{\star * 1}$ & $.278^{\star *}$ & $.261^{\star \star}$ & 1 \\
\hline & Sig. (2-tailed) & .001 & .000 & .714 & .019 & .000 & .000 & .000 & \\
\hline & $\mathrm{N}$ & 440 & 440 & 440 & 440 & 440 & 440 & 440 & 440 \\
\hline
\end{tabular}

\section{Results And Discussions}

Main objective of this study was to examine and assess the quality of services delivered to the passengers by the only public transport of the country. To measure the passenger perceptions about the quality of services delivered during travelling or making travelling arrangements, a modified SERVQUAL instrument was used. Eight service quality constructs comprised of 31 variables were used. Statistical analysis of this study provide us an insight about the passenger dissatisfaction about the service quality of rail transport system in India. The mean responses against all the parameters used to measure the service quality mentioned in table 2 are 1 which indicates that majority of the respondents showed dissatisfaction. The overall structure equation model build to study the service quality of rail transport system based on passenger's perception provides dissatisfaction against all the parameters of service quality. However, only one parameter namely, tangibles provide passengers satisfaction. Passengers were satisfied with the cleanliness both in the coach, platforms and washrooms, lighting and air-conditioning in the coach was adequate, seats were comfortable and there was proper sitting facilities for the passengers at platforms. There were proper parking facilities for the people who came to receive or drop the passengers at platforms. As rail transport system was one of the best public transport systems in India and it was established during the British rule in India in 1861 and after independence in 1947 it started operation government of India and way then know as Indian Railways. Earlier majority of the cities of India were connected with the railway tracks and still only source of transportation from Delhi to Kerala and from Assam to Mumbai.

During the last couple of years the rail transport system is declining day by day due to lack of planning and wrong strategies and now it has become more worst. Safety measure had not been taken properly; poor information system and the passengers had to face a lot of problems before, after and sometime during travelling and our findings validate these facts. The personals involved in the operations of rail transport system looks to be de-motivated and don't try to make any efforts to provide comfort during any emergencies or even in routine dealings with the passengers.

\section{Conclusions}

Overall empirical findings of this study are evident that passenger perceive that rail transport system, the main public sector transport, is not providing good quality of services that can meet their expectations. It is also evident that visible efforts by Indian Railways should be in place to improve or upgrade the rail transport system. In summary service quality of rail transport is regarded as critical indicator that would enhance its customer's satisfaction.

However, findings of this study will helpful for the managers in strategy making and future planning. There are some limitations of this study as it was conducted in one city and with a limited number of respondents therefore, results of this study cannot be generalized.

The empirical nature of this study is really a contribution to identify the factors that determine passenger satisfaction in train with service quality of services provided by the Indian Railways. The quality of 
service that mostly affect the satisfaction of passengers (customers) in rank order is Responsiveness, Catering, Tangibility, Assurance, Safety, Information, and lastly and the least important factor is Punctuality, towards Passengers. The Indian Rail transportation is gaining importance day by day. With the increase of passengers, the Indian Railways has focused to extend its attention to satisfy the needs of customers and made initiatives to improve the quality of service to enrich the satisfaction of customers. Even though repeated attempt made by the Railways to improve the quality of services, the result would not satisfied the customers (passengers) needs. This reveals that, continuous, comprehensive, lengthy intentional performance and attempts are essential to fill these service gaps. Accordingly, the researcher gives some insights to develop and improve the quality of services to satisfy the passengers.

\section{Reference:}

[1]. Fatma Pakdil and Timothy N. Harwood, 2005. Patient Satisfaction in a Preoperative Assessment Clinic: An Analysis Using SERVQUAL Dimensions, Total Quality Management, 16(1): 15-30.

[2]. Biema, V.M. and B. Greenwald, 1997. Managing our way to higher service-sector productivity, Harvard Business Review, JulyAugust, pp: 87-95.

[3]. Raghuram and Rachana Gangwar, "Indian Railways in the Past Twenty Years Issues, Performance and Challenges", W.P. No. $2008-07-05,200$

[4]. Gronroos, C., 1988. Service quality: the six criteria of good perceived service, Review of Business, 9(3): 10-13.

[5]. Stock, J.R. and D.M. Lambert, 1992. Becoming a 'World Class' company with logistics service quality, The International Journal of Logistics Management, 3(1): 73-81.

[6]. Kuei, C., 1998. Service quality, in: C.N. Madu (Ed.) Handbook of Total Quality Management (New York: Kluwer Academic Publishers).

[7]. Rapert, M.L. and B.M. Wren, 1998. Service quality as a competitive opportunity, Journal of Service Marketing, 12(3): 223-33

[8]. Hadikoemoro, S., 2002. A comparison of public and private university students' expectations and perceptions of service quality in Jakarta, Indonesia, unpublished PhD dissertation, Nova Southern University, Davie, FL.

[9]. Berry, L.L., D.R. Bennet and C.W. Brown, 1989. Service Quality: A Profit Strategy for Financial Institutions. Dow-Jones-Irwin, Homewood, IL.

[10]. Reichheld, F.F. and W.E. Sasser, 1990. Zero defections: quality comes to service, Harvard Business Review, 68(5): 105-11.

[11]. Rust and Anthony J. Zahorik, 1993. Customer Satisfaction, Customer Retention and Market Share. Journal of Retailing, 69: 193215.

[12]. Spreng, R.A. and R.D. MacKoy, 1996. An empirical examination of a model of perceived service quality and satisfaction. Journal of Retailing, 72(2): 201-14

[13]. Cronin, J.J., M.K. Brady and G.T.M. Hult, 2000. Assessing the effects of quality, value and customer satisfaction on consumer behavioural intentions in service environment, Journal of Retailing, 76(2): 193-218.

[14]. Yoon, S. and H. Suh, 2004. Ensuring IT consulting SERVQUAL and user satisfaction: a modified measurement tool, Information Systems Frontiers, 6(4): 341-51

[15]. Kang, G.D. and J. James, 2004. Service quality dimensions: an examination of Gro"nroos's service quality model, Managing Service Quality, 14(4): 266-77.

[16]. Tyrinopoulos, Y. and C. Antoniou, 2008. Public transit user satisfaction: Variability and policy implications. Transport Policy, 15: 260-272.

[17]. Hensher, D.A., P. Stopher and P. Bullock, 2003. Service quality-developing a service quality index in the provision of commercial bus contracts. Transportation Research Part A, 37: 499-517.

[18]. Swanson, J., L. Ampt and P. Jones, 1997. Measuring bus passenger preferences. Traffic Engineering and Control, 38: 330-336

[19]. Eboli, L. and G. Mazzulla, 2007. Service quality attributes affecting customer satisfaction for bus transit. Journal of Public Transportation, 10: 21-34.

[20]. Eriksson, L., M. Friman and T. Gärling, 2009. Stated reasons for reducing work commute by car. Transportation Research Part F: Traffic Psychology and Behavior, 11: 427-433.

[21]. Smith, M.J. and R.V. Clarke, 2000. Crime and public transport. In: Tonry, M. ed. Crime and Justice: A Review of Research 27. Chicago: University of Chicago Press.

[22]. Fellesson, M. and M. Friman, 2008. Perceived satisfaction with public transport services in nine European cities. The Journal of Transportation Research Forum, 47: 93-103, Transit Issue Special.

[23]. Friman, M. and T. Gärling, 2001. Frequency of negative critical incidents and satisfaction with public transport services. II. Journal of Retailing and Consumer Services, 8: 105-114.

[24]. Sachdev, S.B. and H.V. Verma, 2004. Relative importance of service quality dimensions: a multi-sectoral study. Journal of Services Research, 4(1): 93-116

[25]. V.A. Parasuraman, A. Zeithaml, L. Berry. A Conceptual Model of Service Quality and Its Implications for the Future Research. Journal of Marketing. 1985. Vol. 49, pp.41-50.

[26]. V.A. Zeithaml, A. Parasuraman, L.L. Berry. Delivering quality service: Balancing customer perceptions and expectations. 1990. New York: The Free Press.

[27]. P. Kotler, G. Amstrong. Principles of Marketing, 11th Ed., New Jersey, Pearson Prentice Hall 2006.

[28]. A. Q. Othman, L. Owen. The Multidimensionality of Carter Model to Measure Customer Service quality (SQ) in Islamic Banking Industry: A Study in Kuwait Finance House. International Journal of Islamic Financial Services. 2000. 3(4).

[29]. A. Q. Othman, L. Owen. Adopting and Measuring Customer Service Quality in Islamic Banks: A Case Study in Kuwait Finance House”, International Journal of Islamic Financial Services. 2001. 1(3): 6-12.

[30]. H. Sudin, W. Nursofiza. S. Shafie. Adopting and Measuring Customer Service Quality (SQ) in Islamic Banks: A Case Study in Bank Islam Malaysia Berhad. Proceedings of National Seminar in Islamic Banking and Finance, Putrajaya, Kuala Lumpur, 2004.March, 91-102.

[31]. M.T. Izah, W. Z. W. Ismail. Service Quality in the Financial Services Industry in Malaysia: The Case of Islamic Banks and Insurance. International Review of Business Research Papers. 2005. 1(2): 10-21.

[32]. Parasuraman, A., V. Zeithaml and L. Berry, 1988. SERVQUAL: a multiple item scale for measuring consumer perceptions of service quality. Journal of Retailing, 64(1): 12-40. 
[33]. Riadh Ladhari, 2009. A review of twenty years of SERVQUAL research, International Journal of Quality and Service Sciences, 1(2): 172-198.

[34]. Luna-Arocas, R. and J. Camps, 2008. A Model of High Performance Work Practices and Turnover Intentions, Personnel Review, 37: $26-46$.

[35]. Gatewood, R. and H. Field, 1990. Human Resource Selection, 2nd ed., The Dryden Press, Cleveland, OH.

[36]. Green, S., N. Salkind and T. Akey, 2000. Using SPSS for Windows: Analyzing and Understanding Data, 2nd ed., Prentice-Hall, Upper Saddle River, NJ.

[37]. Nunnally, J., 1978. Psychometric Theory, McGraw Hill Book Co., New York, NY.

[38]. Seo, Y.W., H.S. Han and J.N. Lee, 2005. A relationship perspective to investigate the effect of human resource capability on information system outsourcing success. Research and Practice in Human Resource Management, 13(2): 1-15.

[39]. Bentler, P.M., 1990. Comparative fit indexes in structural equation models. Psychological Bulletin, 107: $238-246$.

[40]. Hu, L.T. and P. Bentler, 1999. Cutoff criteria for fit indexes in covariance structural analysis: Conventional criteria versus new alternatives. Structural Equation Modelling, 6: 1-55.

[41]. Browne, M.W. and R. Cudeck, 1993. Alternative ways of assessing model fit. In K.A. Bollen and J.S. Long, (Eds.), Testing structural equations models. Newbury Park, CA: Sage.

[42]. Byrne, B.M., 2001. Structural equation modeling with AMOS. Mahwah, NJ: Lawrence Erlbaum Associates.

[43]. Byrne, B.M., 1998. Structural Equation Modeling With LISREL, PRELIS and SIMPLIS, Basic Concepts, Applications and Programming, Lawrence Erlbaum Associates, Inc., Mahwah, New Jersey.

[44]. De Jong, G., 1999. Causal Loops in Long-Term Supply Relationships: Theory and Evidence from the United States, Japan and Europe, PhD thesis, SOM, University of Groningen, The Netherlands.

\section{ABOUT THE AUTHORS}

V. Rajeswari is currently working as a Research Scholar, Department of Economics, S.V.University College, Tirupati. Prior to academics, she worked as Lecturer in Economics, SATAVAHANA DEGREE COLLEGE, VIJAYAWADA. For Nine years( 19942003)

Prof. K. Santha Kumari is currently working as Professor, Dept. of Economics, S.V. University, Tirupati. Research Areas: Public Finance and Banking. Memberships in professional bodies Life Member - Indian Economic Association, A.P.Economic Association, Indian Institute of Public Administration

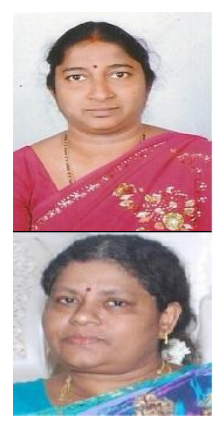

